\title{
Bio-optical characterization and light availability parameterization in Uummannaq Fjord and Vaigat-Disko Bay (West Greenland)
}

\author{
L. Holinde and O. Zielinski \\ Institute for Chemistry and Biology of the Marine Environment, University of Oldenburg, \\ Carl-von-Ossietzky-Str. 9-11, 26129 Oldenburg, Germany \\ Correspondence to: L. Holinde (lars.holinde@uni-oldenburg.de)
}

Received: 4 June 2015 - Published in Ocean Sci. Discuss.: 21 July 2015

Revised: 8 December 2015 - Accepted: 13 December 2015 - Published: 15 January 2016

\begin{abstract}
This study investigated the bio-optical conditions of Uummannaq Fjord and Vaigat-Disko Bay, two neighboring, semi-enclosed coastal systems in West Greenland. Though close to each other, the systems differ in their hydrographic structure influencing the bio-optical conditions and, subsequently, the biological activities. Both systems showed high inorganic suspended particulate matter (SPMi) concentrations near river runoff or meltwater influxes (max. of $15.28 \mathrm{mg} \mathrm{L}^{-1}$ at the surface) and low colored dissolved organic matter (aCDOM@350nm, $<1.50 \mathrm{~m}^{-1}$ ) abundance throughout the systems. High chlorophyll levels (as an indicator of phytoplankton biomass) were measured in the Vaigat (max. of $11.44 \mu \mathrm{g} \mathrm{L}^{-1}$ ), which represents the outflow arm of Disko Bay. Light penetration depth as indicated by the $1 \%$ depth of photosynthetically available radiation (PAR) was dominated by chlorophyll and SPMi alike, ranging from 12.2 to $41.2 \mathrm{~m}$. Based on these characteristics, an effective twocomponent parameterization for the diffuse attenuation coefficient $k_{\text {PAR }}$ was developed in order to model light penetration depth as a relevant factor for bio-optical studies in Arctic environments under glacial meltwater influence.
\end{abstract}

\section{Introduction}

Greenland's coastal systems are strongly influenced by their ocean and land boundaries. Land-based influences include freshwater influx from glacial meltwater or river runoff (Straneo and Cenedese, 2015), while oceanic influences include adjacent waters from the Nordic Seas, Baffin Bay and coastal currents. Mixing and exchange between these land and ocean-derived waters are also controlled by the presence of sills, which can restrict water exchange (Straneo et al., 2012).

Climate-driven warming significantly affects the hydrography of these coastal systems through glacial melting and freshwater runoff, and Disko Bay (West Greenland, Andersen, 1981), which is fed by the Jakobshavn Isfjord, is especially subject to these dynamics (Hansen et al., 2012). During an expedition with R/V Maria S. Merian in JulyAugust 2012 (MSM 21/3), we investigated the optical, physical, and biological properties of waters in the Vaigat-Disko Bay and the nearby Uummannaq Fjord in West Greenland. The overall goal of this research cruise focused on characterizing phytoplankton species distribution and abundance in Arctic waters, particularly taxa associated with harmful algal blooms (HABs) (Cembella et al., 2013; Garaba and Zielinski, 2013). The expedition coincided with an increase in Jakobshavn Isbræ glacier melting activity as reported by Joughin et al. (2014) and an unprecedented surface melt of the Greenland ice sheet in 2012 (Nghiem et al., 2012).

The optical properties of these coastal water bodies are reported to be influenced by small particles transported by river runoff and meltwater. Lund-Hansen et al. (2010) analyzed the optical properties of the Kangerlussuaq Fjord, West Greenland, highlighting the importance of the very fine particle fraction $(2-6 \mu \mathrm{m}$, also denoted as glacial flour) in determining the underwater light field. Light availability is a major factor in phytoplankton growth (Bannister, 1974; Vahtera et al., 2014; Etherington et al., 2007), including bloom initiation and development in the euphotic zone (Platt and Sathyendranath, 1988; Behrenfeld and Falkowski, 1997), which is limited by the $1 \%$ depth as its lower boundary. Climate-driven changes are impacting underwater light 

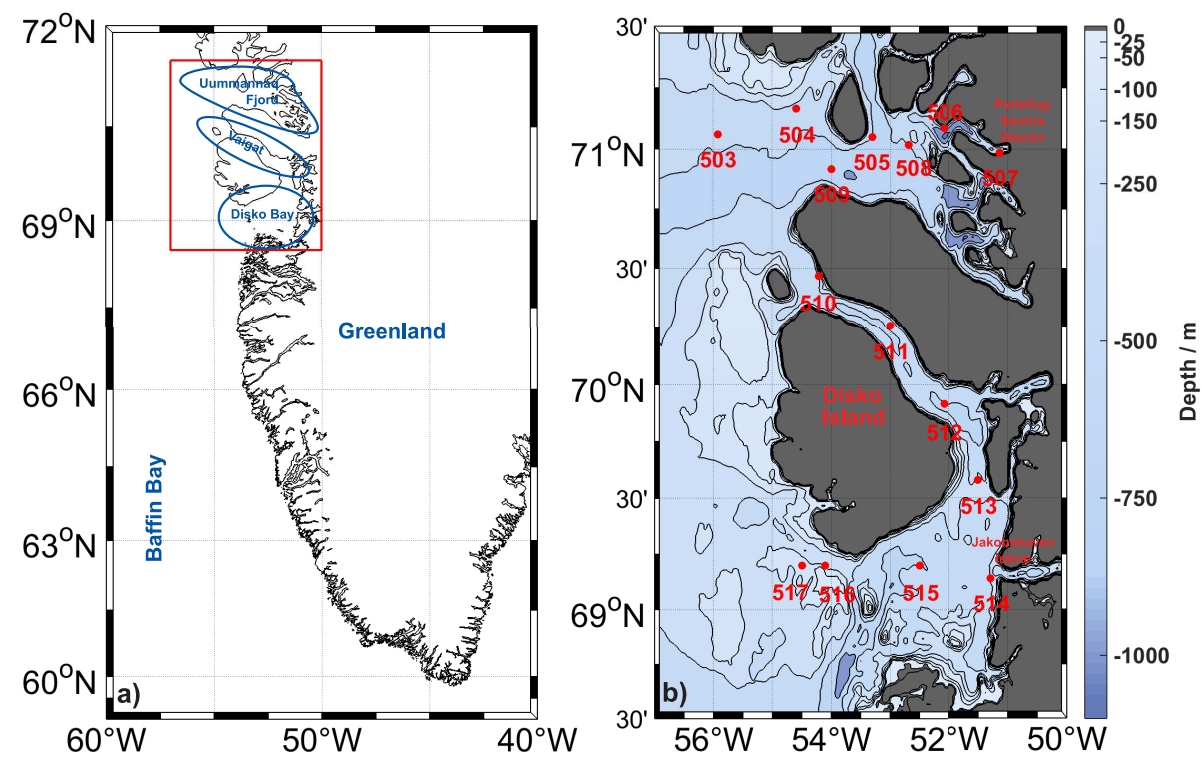

Figure 1. (a) Map of Greenland and parts of Baffin Bay; (b) study area: Uummannaq Fjord, Vaigat and Disko Bay (West Greenland) with stations (red dots) and under water topography (data from Amante and Eakins, 2009). The contour lines represent the indicated depth at the color bar next to the map.

fields, thus influencing light available to phytoplankton, including species responsible for HABs (Moore et al., 2008).

The objective of this study was to characterize and compare the bio-optical conditions of two coastal systems in West Greenland that are located in the same geographical area but governed by differing hydrography and geography. To achieve this goal, we investigated the distribution of chlorophyll $a(\mathrm{Chl} a)$, inorganic suspended particulate matter (SPMi), and colored dissolved organic matter (CDOM), and determined the resulting light penetration depth of the photosynthetically available radiation (PAR) based on field observations. These data and results were used to derive an effective two-component model for PAR in the water column based on Chl $a$ and SPMi observations, thus enabling an assessment of the $1 \%$ light availability depth in both systems in a novel integrated physical-bio-optical representation.

\section{Research area and methods}

\subsection{Research area}

Expedition MSM 21/3 (Cembella et al., 2013) departed Nuuk (Greenland) on 25 July and ended on 10 August 2012 in Reykjavik (Iceland). Data shown in this paper were collected from Uummannaq Fjord, Vaigat, and Disko Bay (Fig. 1).

Uummannaq Fjord is situated on the western coast of Greenland, with its mouth at $71^{\circ} \mathrm{N}$ and $55^{\circ} \mathrm{W}$. The fjord's main orientation is southeast to northwest, and includes several inlets and tributaries. One such tributary is the Perlerfiup Kangerlua Fjord, which flows into Uummannaq at $71.05^{\circ} \mathrm{N}$ and $52^{\circ} \mathrm{W}$ near Alfred Wegener Halvø (station 506) and is bordered to the east by the Perlerfiup Sermia glacier (station 507). The fjord system is strongly influenced by meltwater runoff from inland glaciers and opens to the west towards the oceanic waters of Baffin Bay (Tang et al., 2004; Zweng and Munchow, 2006; Melling et al., 2010). The system is also influenced by the West Greenland coastal current, which flows from south to north (Cuny et al., 2005; Munchow et al., 2006).

The Vaigat-Disko Bay area is located just south of Uummannaq Fjord and, in contrast to the fjord, is an open system in which water enters on the southwestern end of Disko Bay and either flows through the Vaigat (stations 510-513) or joins a westward counter-current south of Disko Island (Ribergaard et al., 2004). The Vaigat is also strongly influenced by meltwater runoff, as well as the Jakobshavn Isfjord near station 514, and is fed by three glaciers and transports huge numbers of icebergs into Disko Bay (Joughin et al., 2014).

\subsection{Methods}

\subsubsection{In situ measurements}

Measurements were performed at seven stations in Uummannaq Fjord (Fig. 1b, 503-509) and eight stations in the VaigatDisko Bay area (Fig. 1b, 510-517) (Table 1). At each station, data on water column properties were collected using a CTD rosette sampler (Seabird SBE 911+, Sea-Bird Electronics Inc., USA) and used to determine hydrographic structure. Data from the top $3 \mathrm{~m}$ were discarded because of influences from the CTD deployment and vessel movement. Attached to the CTD probe was a rosette sampler with 24 free flow 
Table 1. Accuracy of in situ instruments used in this paper (FS: full scale).

\begin{tabular}{llr}
\hline Instrument & Parameter & Accuracy \\
\hline CTD & Conductivity $\left(\mathrm{S} \mathrm{m}^{-1}\right)$ & $<0.008 \mathrm{~S} \mathrm{~m}^{-1}$ \\
CTD & Temperature $\left({ }^{\circ} \mathrm{C}\right)$ & $<0.006^{\circ} \mathrm{C}$ \\
CTD & Pressure $(\mathrm{m})$ & $<0.06 \% \mathrm{FS}$ \\
ECO-AFL/FL & Fluorescence $\left(\mu \mathrm{g} \mathrm{L}^{-1}\right)$ & $0.025 \mu \mathrm{g} \mathrm{L}-1$ \\
ECO-AFL/FL & Turbidity $(\mathrm{NTU})$ & $0.01 \mathrm{NTU}$ \\
Profiler & Pressure $(\mathrm{dBar})$ & $<0.01 \% \mathrm{FS}$ \\
HyperOCR Radiometer & Downwelling irradiance $\left(500 \mathrm{~nm}, 1024 \mathrm{~m} \mathrm{~s}^{-1}\right.$ & $<1 \%$ \\
& integration time, $\left.\mu \mathrm{W} \mathrm{cm} \mathrm{cm}^{-2} \mathrm{~nm}^{-1}\right)$ & $<1 \%$ \\
HyperOCR Radiometer & Reference irradiance $\left(500 \mathrm{~nm}^{-1}\right) 24 \mathrm{~m} \mathrm{~s}^{-1}$ & \\
& integration time, $\left.\mu \mathrm{Cm}^{-2} \mathrm{~nm}^{-1}\right)$ & $0.003 \mathrm{~m}^{-1}$ \\
\hline
\end{tabular}

bottles and a combined turbidity-fluorometer sensor (ECOAFL/FL, WET Labs, USA, 470/695 nm fluorescence) for bio-optical measurements (Moore et al., 2009). Water samples were collected during the upcast at 3,8 , and $15 \mathrm{~m}$, at deep chlorophyll maximum, and from greater depths, depending on the downcast measurements. These water samples were used to quantify total and inorganic suspended particulate material (SPM) and chlorophyll $a(\mathrm{Chl} a)$ concentrations. In addition, filtered water samples were analyzed with an AquaLog (Horiba Ltd., Japan) for absorption measurements (see below).

Depending on daylight and weather conditions, measurements of the underwater light field and further bio-optical parameters were conducted utilizing a HyperPro II Profiler (Satlantic Inc., Canada). At these stations, three casts were performed by lowering the profiler until the downwelling irradiance values were on the same order of magnitude as what the instrument would measure in total darkness (dark current). For these measurements, the profiler was lowered into the water at least $30 \mathrm{~m}$ behind the vessel to avoid ship shadowing when free falling. This profiler featured a sensor measuring downward irradiance $\left(E_{\mathrm{d}}\right.$, HyperOCR Radiometer, Satlantic Inc., Canada) as well as an integrated CTD for depth measurements. In addition, an ECO puck sensor (WET Labs, USA) was installed in the profiler and configured to measure backscatter intensities at $700 \mathrm{~nm}$. A downward irradiance ( $E_{\mathrm{s}}$, HyperOCR Radiometer, Satlantic Inc., Canada) reference sensor was mounted at an elevated, non-shaded location. Profiler data processing and calculation of desired parameters (backscatter and PAR) were performed with ProSoft 7.7.16 (Satlantic Inc., Canada), with data processed using $0.2 \mathrm{~m}$ depth bins and $5 \mathrm{~nm}$ wavelength bins. After processing with ProSoft, the depth grid was changed to $0.25 \mathrm{~m}$ bins and the mean of all profiles at each station was calculated to provide average light field data for later processing.

\subsubsection{Laboratory measurements}

Table 2 provides an overview of the laboratory methods used to determine SPMi and CDOM, and their uncertainties. Water samples collected during the CTD casts were filtered using glass fiber filters (Whatman GF/F) with a mean pore size of $0.7 \mu \mathrm{m}$ to obtain SPM concentrations. Prior to the cruise, these filters were heated at $500{ }^{\circ} \mathrm{C}$ for $5 \mathrm{~h}$ to remove biological residue and washed with ultrapure water to remove further remains. After drying at $60^{\circ} \mathrm{C}$ for at least $6 \mathrm{~h}$, the filters were weighed (Kern 770-60, KERN \& SOHN GmbH, Germany) and packed individually. During the cruise, a defined water volume between 1 and $8 \mathrm{~L}$ (depending on water turbidity) was filtered. After filtration the filters were frozen at $-20^{\circ} \mathrm{C}$. Following the cruise, the filters were dried at $60^{\circ} \mathrm{C}$ for at least $6 \mathrm{~h}$ and weighed to obtain total SPM content, and then heated to $500^{\circ} \mathrm{C}$ for $5 \mathrm{~h}$ and weighed a final time to obtain the inorganic SPM concentration.

For concentrations of Chl $a$, water volumes between 100 and $500 \mathrm{~mL}$ were filtered under low vacuum through Whatman GF/F filters with a nominal pore size of $0.7 \mu \mathrm{m}$, and then immediately frozen at $-80^{\circ} \mathrm{C}$. Pigment extraction was performed in a $90 \%$ acetone solution, overnight at $4{ }^{\circ} \mathrm{C}$. The extract was centrifuged for $10 \mathrm{~min}$ at $3020 \times g$. Fluorescence of the supernatant was measured with a pre-calibrated TD700 laboratory fluorometer (Turner Designs, Sunnyvale, CA, USA). Computation of Chl $a$ concentration $\left(\mu \mathrm{g} \mathrm{L}^{-1}\right)$ was done according to the EPA Method 446.0 protocol (Arar, 1997).

CDOM analysis was performed using a spectrofluorometer (AquaLog, Horiba Ltd., Japan) configured for measurements and calculation of CDOM absorption at different wavelengths (utilizing the photometer accessory of the AquaLog). For these measurements, water samples were filtered through a $0.2 \mu \mathrm{m}$ filter (membrane filter, Whatman) and dispensed into a cuvette with a path length of $1 \mathrm{~cm}$. Prior to sample analysis, the cuvette was rinsed with purified water (MilliQ) and then twice with sample water. The chamber 
Table 2. Uncertainties and accuracy for laboratory methods and instruments.

\begin{tabular}{lllllll}
\hline Parameter & Unit & Filter volume error & System & Accuracy & Method error & Total error \\
\hline SPM & $\mathrm{mg} \mathrm{L}^{-1}$ & $<5 \%$ & Kern 770-60 & $<1 \%$ & $5 \%$ & $<11 \%$ \\
Chl $a$ & $\mu \mathrm{g} \mathrm{L}^{-1}$ & $<5 \%$ & TD-700 & $<1 \%$ & $10 \%$ & $<16 \%$ \\
CDOM & $\mathrm{m}^{-1}$ & - & Aqualog & $<5 \%$ & $5 \%$ & $<10 \%$ \\
\hline
\end{tabular}

used for these analyses was maintained at $20^{\circ} \mathrm{C}$ in a stabilized therobath to ensure measurement consistency.

\subsubsection{Comparison between in situ and laboratory data}

To correlate in situ Chl $a$ fluorescence and laboratory Chl $a$ concentrations, the saturation behavior of the fluorescence signal was expressed using Eq. (1) (Duyens, 1956):

Chl $a_{\text {fluo }}=a \times \exp \left(-b \times \operatorname{Chl} a_{\text {con }}\right)+a$.

SPMi concentrations were calculated from turbidity readings following Gohin (2011), which takes into account the measured Chl concentrations as a proxy for organic SPM:

Turbidity $=c \times\left(\mathrm{SPMi}+0.234 \times \mathrm{Chl} a_{\mathrm{con}}^{0.57}\right)$.

After solving for both equations, the equations were used to derive Chl $a$ and SPMi concentrations from measured biooptical properties.

\subsubsection{Calculation of PAR}

As mentioned above, light profile availability was limited to daylight conditions. Therefore, we adopted a simplified PAR model (compare Zielinski et al., 2002) to investigate the impact of different PAR representations. According to Paulson and Simpson (1977) and Buiteveld (1995), it is possible to derive PAR at the depth $z$ with the following simple relation:

$\operatorname{PAR}(z)=\operatorname{PAR}(0) \times \exp \left(-k_{\mathrm{PAR}} \times z\right)$,

with (according to Gohin et al., 2005; Nelson and Smith, 1991)

$k_{\mathrm{PAR}}=d+e \times \mathrm{SPMi}+f \times\left(\mathrm{Chl} a_{\mathrm{con}}^{g}\right)$.

In Eq. (4) the coefficient $d$ represents the combined influence of pure sea water and CDOM absorption on the diffuse absorption coefficient $k_{\mathrm{PAR}}$. Coefficients $e$ and $f$ represent the combined specific absorption and scattering factor for SPMi and Chl $a$, respectively, and $g$ the non-linearity of Chl $a$ abundance and its absorption (e.g., by the packaging effect). Whereas in most simple models $k_{\mathrm{PAR}}$ is considered constant for the water column, in our case the values for inorganic SPM (SPMi) and Chl $a$ were variable. Therefore we modified Eq. (3) in the following iterative way:

$\operatorname{PAR}(z(i))=$

$\operatorname{PAR}(z(i-1)) \times \exp \left(-k_{\mathrm{PAR}} \times(z(i)-z(i-1))\right)$.

The $1 \%$ depth of PAR was calculated by solving Eq. (5), assuming $100 \%$ at the top of the water column, and then estimating the depth nearest to $1 \%$.

\section{Results}

\subsection{Data overview}

Data obtained during expedition MSM 21/3 are available at World Ocean Data Center PANGAEA (Zielinski et al., 2013a, b, c, d). Figures 2 and 3 show the hydrographic and bio-optical conditions in both coastal systems. Data from Uummannaq Fjord are displayed starting at the Perlerfiup Sermia glacier (507) and ending at the ocean boundary (503), whereas data from Vaigat-Disko Bay are displayed following the station numbering. In Uummannaq Fjord a surface layer of warm water of $2-10^{\circ} \mathrm{C}$ was observed, underlain by colder water (around $0^{\circ} \mathrm{C}$ ). The depth of the boundary between these two layers ranged from $10 \mathrm{~m}$ (507 and 509) to $40 \mathrm{~m}$ (504). Salinity levels in Uummannaq Fjord were lowest at station 506, and generally increased with depth throughout the fjord. A warm, shallow surface layer (down to $35 \mathrm{~m}$ at station 510) was also observed at some stations in VaigatDisko Bay. In the Vaigat, temperatures of this surface layer were generally colder than in the fjord. A very cold surface layer $(0-30 \mathrm{~m})$ was observed at station 514 (Jakobshavn Isfjord); however, below this layer, temperatures increased at depths between 30 and $80 \mathrm{~m}$, and again decreased at depths $>80 \mathrm{~m}$. This vertical distribution was similar to other stations. Nearly all stations showed lower salinity levels in the surface layer (to $20 \mathrm{~m}$ ), except those near Jakobshavn Isfjord and south of Disko Island.

Figure 3 shows Chl $a$ fluorescence, turbidity, and PAR. Fluorescence was very low throughout Uummannaq Fjord, with the highest values ( $3 \mathrm{RU}$ ) measured in a thin layer around $25 \mathrm{~m}$ depth at stations near the ocean boundary (stations 503 and 504). Low values were also found in Disko Bay, but higher measurements were obtained from the inner stations in the Vaigat, with the maximum value recorded at the top of the water column at station 512 (up to $8 \mathrm{RU}$ ). The highest turbidity levels (up to $2 \mathrm{NTU}$ ) were measured 

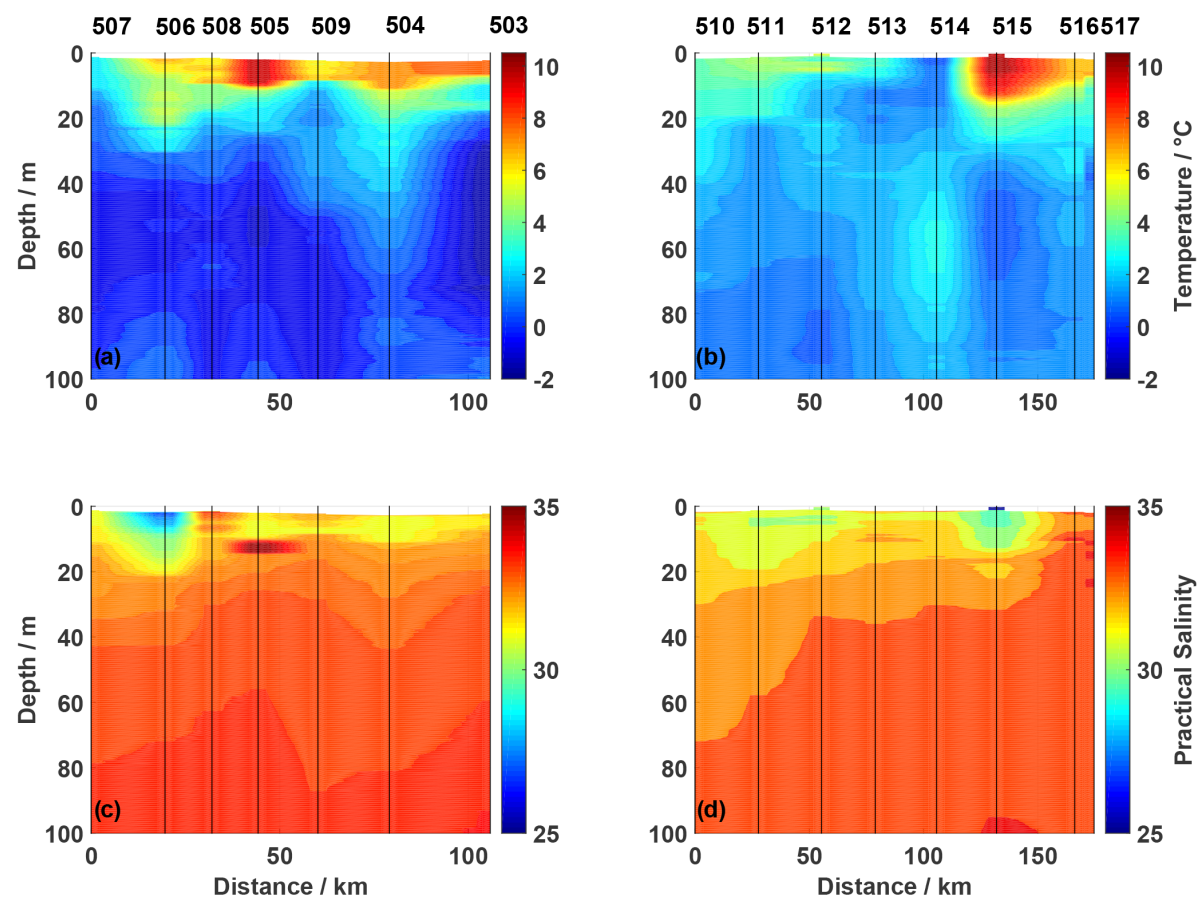

Figure 2. Hydrographic conditions in the Uummannaq Fjord (left, a and c) and in Vaigat-Disko Bay (right, b and d). Temperature is shown the top and salinity at the bottom.
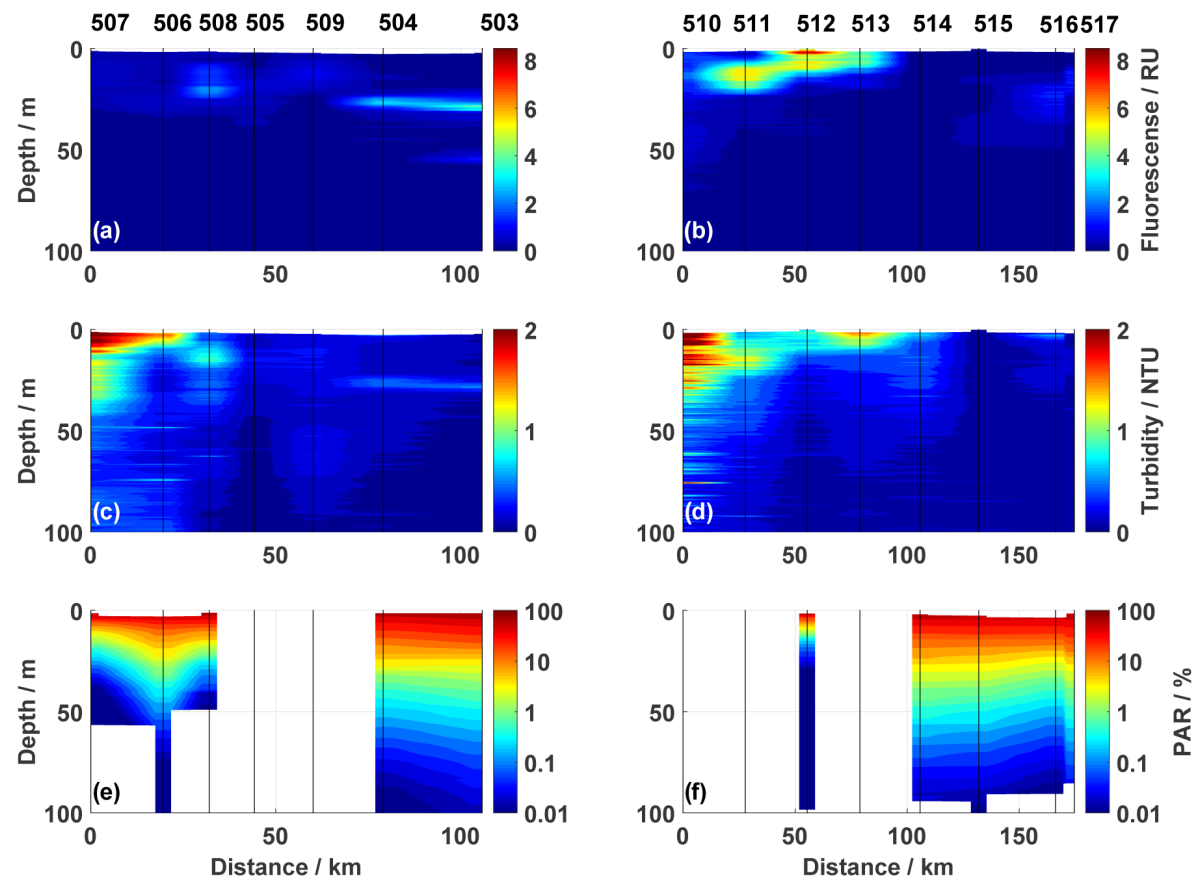

Figure 3. Bio-optical conditions in the Uummannaq Fjord (left, a, c and e) and in Vaigat-Disko Bay (right, b, d and f). The Chl $a$ fluorescence is shown at the top, turbidity in the middle and PAR in \% of surface PAR at the bottom. 
Table 3. Statistics of oceanographic and bio-optical data from Uummannaq Fjord and in Vaigat-Disko Bay. Each column is subdivided into minimum (min), maximum (max), mean and standard deviation (SD).

\begin{tabular}{lrrrr|rrrr}
\hline & \multicolumn{3}{c|}{ Uummannaq Fjord } & \multicolumn{4}{c}{ Vaigat-Disko Bay } \\
\cline { 2 - 8 } & Min & Max & Mean & SD & Min & Max & Mean & SD \\
\hline Temperature $\left({ }^{\circ} \mathrm{C}\right)$ & -1.55 & 9.65 & 1.95 & 1.33 & 0.53 & 10.20 & 2.24 & 1.01 \\
Practical salinity & 27.45 & 34.94 & 34.03 & 0.69 & 29.74 & 34.52 & 33.80 & 0.67 \\
Chl $a\left(\mu \mathrm{g} \mathrm{L}^{-1}\right)$ & 0.1 & 2.6 & 0.8 & 0.6 & 0.0 & 11.4 & 3.0 & 3.7 \\
SPMi $\left(\mathrm{mg} \mathrm{L}^{-1}\right)$ & 0.7 & 15.3 & 5.1 & 4.4 & 0.1 & 9.1 & 2.0 & 2.4 \\
aCDOM@350nm $\left(1 \mathrm{~m}^{-1}\right)$ & 0.0 & 1.4 & 0.3 & 0.2 & 0.0 & 1.5 & 0.4 & 0.3 \\
PAR 1\% $(\mathrm{m})$ & 17.3 & 38.8 & 29.0 & 9.0 & 11.5 & 41.5 & 33.9 & 12.8 \\
\hline
\end{tabular}
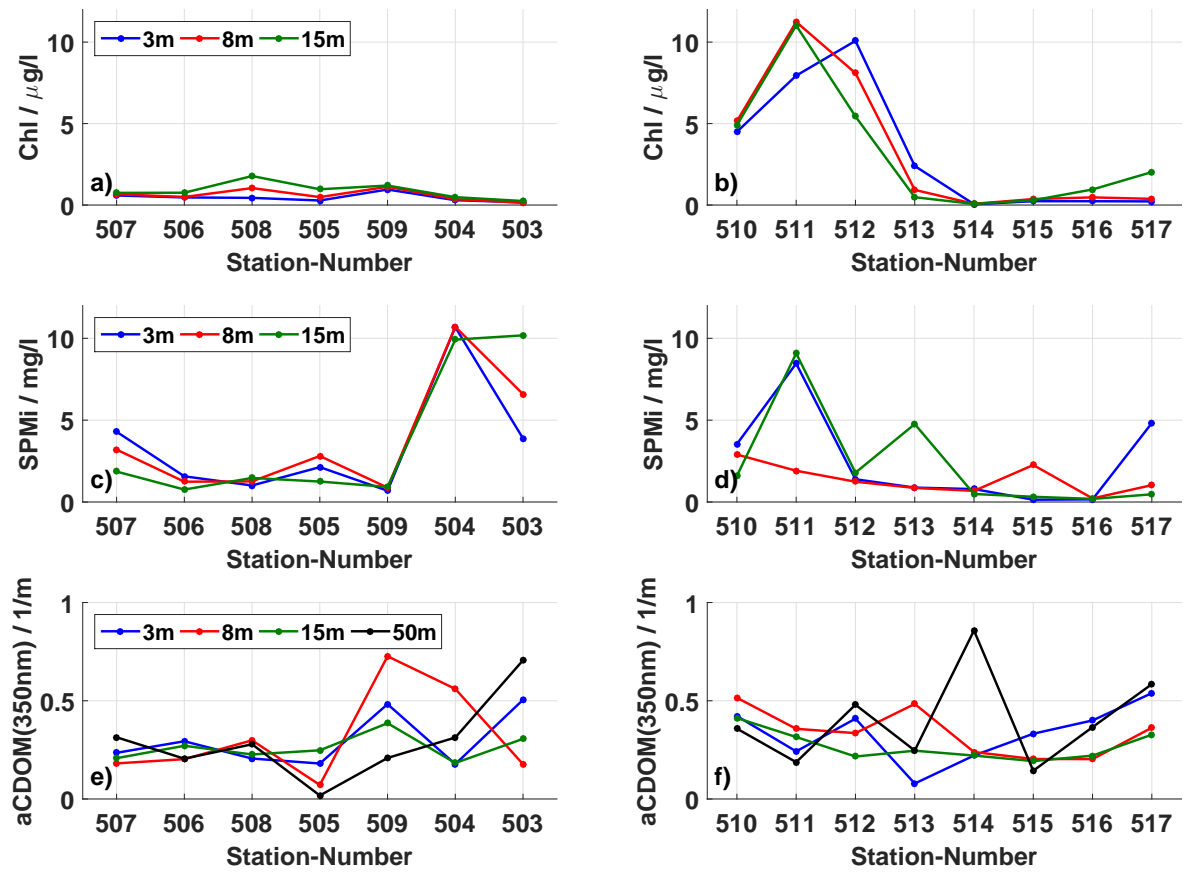

Figure 4. Comparisons of laboratory $\mathrm{Chl} a$ concentrations at $3 \mathrm{~m}$ (blue), $8 \mathrm{~m}$ (red), and $15 \mathrm{~m}$ (green) are presented in (a) (Uummannaq Fjord) and (b) (Vaigat-Disko Bay). Highest concentrations were observed in the Vaigat (510-513). Graphs (c) and (d) show laboratory-sampled SPMi concentrations at the same three depths. CDOM $(350 \mathrm{~nm})$ absorption is displayed in (e) and (f) at the depths mentioned before and in addition at $50 \mathrm{~m}$.

at stations with freshwater runoff or glacier influence. The $1 \%$ depth of PAR ranged from 17.25 to $38.75 \mathrm{~m}$ in Uummannaq Fjord and from 11.5 to $41.5 \mathrm{~m}$ in Vaigat-Disko Bay. These values were strongly related to the fluorescence and turbidity measurements at the respective stations. Note that PAR measurements show some gaps in the data set due to the absence of profiler measurements at some stations. Table 3 summarizes the range, mean, and standard deviation of oceanographic and bio-optical data for both systems. While no significant differences in temperature, aCDOM@350nm, and PAR $1 \%$ depth were observed among locations, SPMi was more abundant in Uummannaq Fjord and the chlorophyll maximum ranges are higher in the Vaigat. Significantly lower salinity levels were observed in Disko Bay, likely due to meltwater influx from Jakobshavn Isbræ.

Chl $a$, SPMi, and CDOM concentrations according to depth are shown in Fig. 4. Highest Chl $a$ concentrations were measured in the Vaigat (510-513), similar to the CTD fluorescence measurements (Fig. 3a and b). In contrast to the turbidity profiles (see Fig. 3c and d) at stations 503 and 504, comparably high SPMi concentrations were derived for these locations. CDOM absorption@350nm varied around $0.35 \mathrm{~m}^{-1}$, with the highest values measured near Jakobshavn Isfjord (514) and at stations closer towards Baffin Bay (503, 509, and 517). 


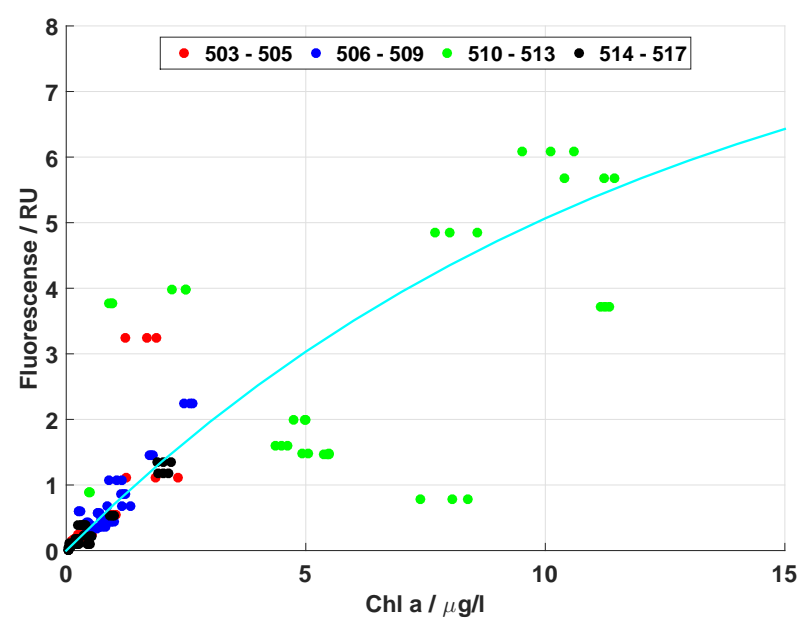

Figure 5. Comparison between $\mathrm{Chl} a$ concentrations and chlorophyll fluorescence for the CTD casts. The cyan line represents Eq. (6). Red and blue dots represent stations in Uummannaq Fjord; green dots are stations in Vaigat and black dots are stations in Disko Bay.

\subsection{Comparison of in situ and sampled data, and modeling of PAR}

Based on the full data set, a multi-parameter fit (MATLAB R2013b) was performed for the exponential correlation of Eq. (1) between Chl $a$ concentration and fluorescence from the same depth yielding

Chl $a_{\text {fluo }}=-9.2 \times \exp \left(-0.08 \times \operatorname{Chl} a_{\text {con }}\right)+9.2$.

Figure 5 shows a scatter plot of Chl $a$ concentration and fluorescence as well as the result of Eq. (6) $\left(R^{2}=0.70\right)$. The error of the unknown coefficients was estimated to be smaller than $17 \%$.

Parameterization of Eq. (2) was derived from sampled SPMi and Chl $a$ concentrations as well as in situ turbidity data from depths where SPMi measurements were available, again using a multi-parameter optimization:

Turbidity $=0.4968 \times\left(\mathrm{SPMi}+0.234 \times\left(\mathrm{Chl} a_{\mathrm{con}}^{0.57}\right)\right)$.

Scatter plots of turbidity and SPMi are shown in Fig. 6a, together with the resulting graph from Eq. (7) $\left(R^{2}=0.70\right)$. High SPMi levels were measured at stations 503-505 (red dots, Fig. 6a) and at certain locations in the Vaigat, with corresponding low turbidity data compared to the correlation for the other measurements. A comparison between backscatter and turbidity signals (Fig. 6b) shows good correlation $\left(R^{2}=0.82\right)$ for all data derived from the two optical in situ methods, suggesting that the highest SPMi measurements from the initial stations of the cruise are erroneous, probably due to long retention times before sampling from the bottles.
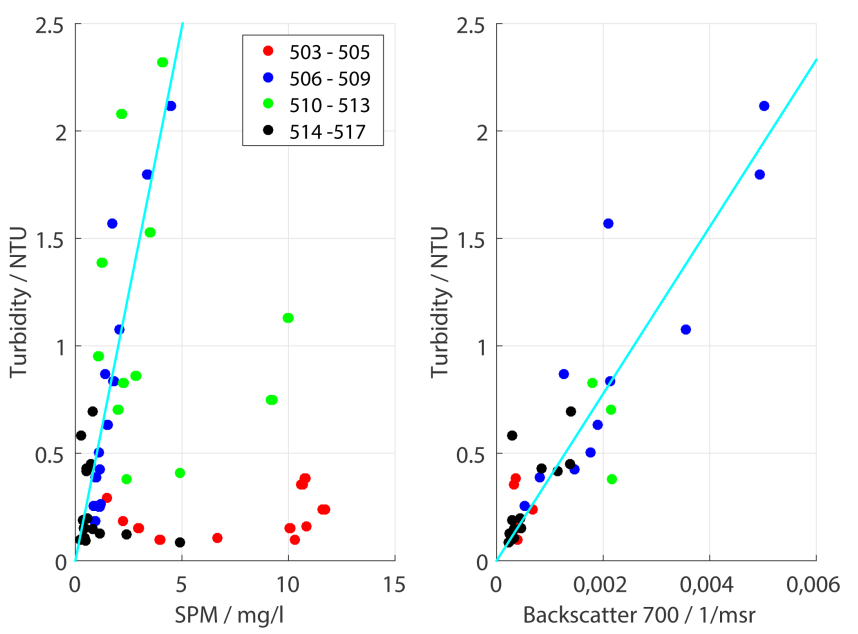

Figure 6. Left: comparison between SPM and turbidity measurements from the CTD casts. The cyan line represents Eq. (7). Right: comparison between backscatter signal at $700 \mathrm{~nm}$ from the profiler and turbidity data from the CTD as well as correlation between the two measurement systems (cyan line). Red and blue dots represent stations in Uummannaq Fjord; green dots are stations in Vaigat and black dots are stations in Disko Bay.

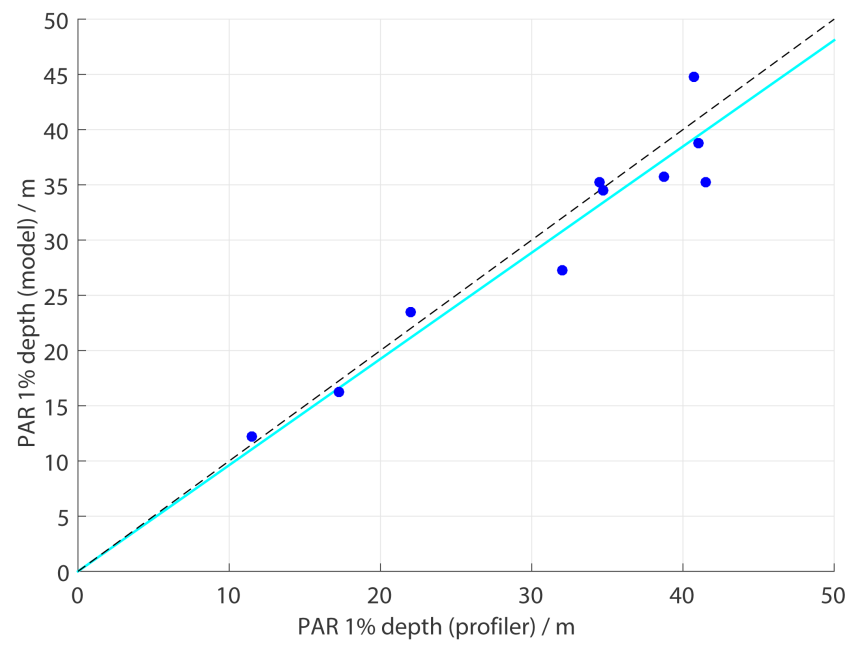

Figure 7. Comparison between measured and modeled 1\% PAR depths. The cyan line represents the best linear correlation between the two parameters $\left(R^{2}=0.92\right)$ and the dashed black line the $1: 1$ correlation.

Due to this time lag, sediment particles in the water sampler may have accumulated at the bottom before the water was sampled. Therefore, these measurements were excluded from the regression. Error of Eq. (7) due to measurement accuracy and methods is smaller than $26 \%$.

Equation (4) was solved using the Curve Fitting Toolbox from MATLAB with default options, and comparison of the sampled data and corresponding available $k_{\mathrm{PAR}}$ measurements from the profiler produced an error smaller than 


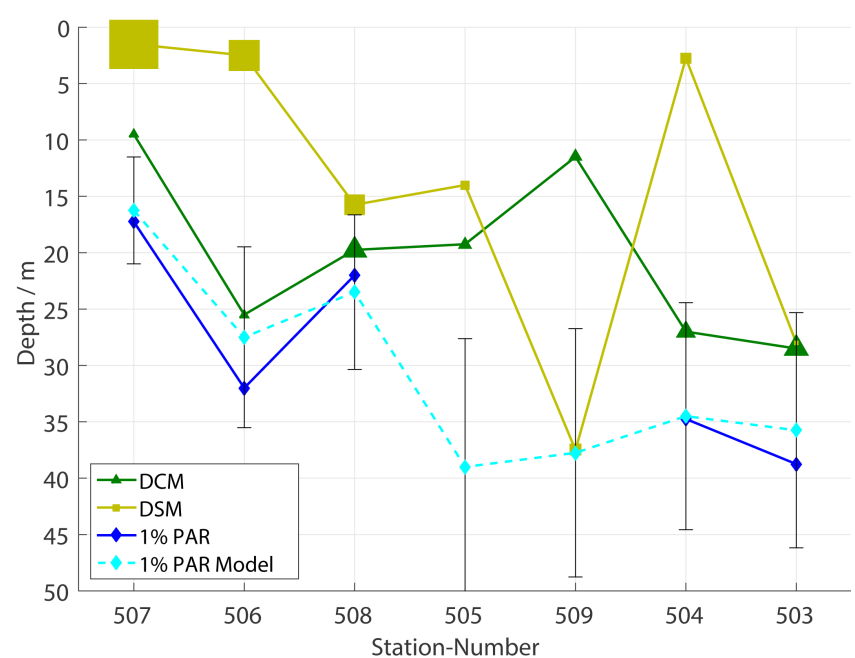

Figure 8. DCM (green, deep chlorophyll max.) and DSM (ocher, deep SPMi max.) at all stations in Uummannaq Fjord from west to east. The size of the markers represents the integrated Chl $a$ and SPMi concentrations from the top of the water column to the modeled $1 \%$ depth. Measured $1 \%$ PAR (blue) where available and modeled $1 \%$ PAR as a dashed line (cyan).

$30 \%$ :

$$
\begin{array}{r}
k_{\mathrm{PAR}}=0.07848+0.0573 \times \mathrm{SPMi}+0.04228 \times\left(\mathrm{Chl} a_{\mathrm{con}}^{0.8226}\right) \\
\left(R^{2}=0.41\right) .
\end{array}
$$

Utilizing Eq. (8), $k_{\mathrm{PAR}}$ was calculated for every depth $z$ and subsequently used in Eq. (5) for calculation of available light in $\%$ at each depth. From these results, the $1 \%$ PAR depth was calculated as the depth with the nearest value to $1 \%$. Figure 7 shows a comparison between the measured and modeled $1 \%$ depth $\left(R^{2}=0.92\right)$. The differences between the measured and modeled data range from 0.7 (504) to $15.1 \%$ (514).

\subsection{Integrated bio-optical representation}

Results of the in situ measurements and calculated values (Eqs. 6 and 7) were integrated into a graphical representation of the bio-optical factors, together with the measured and modeled $1 \%$ depth of PAR (Eqs. 5 and 8). The concentrations of Chl $a$ and SPMi were integrated between the top of the water column and the modeled $1 \%$ PAR depth. The magnitudes of the integrated values in Figs. 8 and 9 are presented by the size of the triangles for Chl $a$ and squares for SPMi at the depth of the Chl $a$ maximum (DCM, deep chlorophyll maximum) or SPMi maximum (DSM, deep SPMi maximum).

Highest integrated concentrations of Chl were observed in the Vaigat (Fig. 9, stations 510-513), with values ranging from 121.9 to $452.8 \mathrm{mg} \mathrm{m}^{-2}$. Integrated concentrations at the other stations ranged from 14.3 to $174.2 \mathrm{mg} \mathrm{m}^{-2}$. Depth

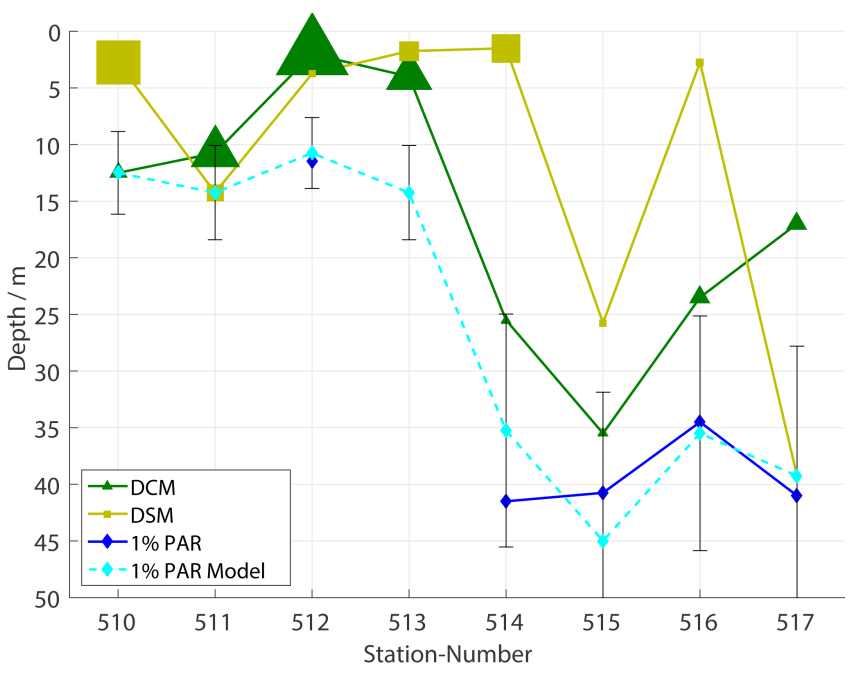

Figure 9. DCM (green, deep chlorophyll max.) and DSM (ocher, deep SPMi max.) at stations in the Vaigat (510-513) and Disko Bay (514-517). The size of the markers represents the sum of Chl and SPMi concentrations from the top of the water column to the modeled $1 \%$ depth. Measured $1 \%$ PAR (blue) where available and modeled $1 \%$ PAR as the dashed line (cyan).

of the DCM ranged from 3 to $12.5 \mathrm{~m}$ in the Vaigat, and from 17 to $35.5 \mathrm{~m}$ in Disko Bay. In Uummannaq Fjord the DCM was found between 9.5 and $28.5 \mathrm{~m}$. At all stations the depth of the Chl maximum was always above or equal to the $1 \%$ penetration depth of PAR.

Integrated SPMi concentrations were highest near the Perlerfiup Sermia glacier (200.6 $\mathrm{g} \mathrm{m}^{-2}$ at station 507) and at the first station in the Vaigat $\left(179.3 \mathrm{~g} \mathrm{~m}^{-2}\right.$ at station 510, located near a runoff). At stations 506 and 507, the SPMi was primarily located near the water surface (Fig. 3c), producing a strong turquoise coloring of the water as observed from above. The overall SPMi concentration generally decreased along a gradient from the semi-enclosed stations to stations nearest to the open ocean in both Uummannaq Fjord and Disko Bay. The depth of the SPMi maximum ranged from 3 to $37.5 \mathrm{~m}$.

The $1 \%$ depth of PAR varied significantly between stations with high $\mathrm{Chl}$ and/or SPMi concentrations and stations where both concentrations were low. The $1 \%$ depth of PAR was lowest in the Vaigat $(11.5 \mathrm{~m})$ and in front of the Perlerfiup Sermia glacier $(17.25 \mathrm{~m})$, whereas in the open areas of Uummannaq Fjord and Disko Bay, the 1\% PAR depth increased to 38.75 and $41.5 \mathrm{~m}$, respectively. The modeled $1 \%$ PAR depth followed the general trend of the measured $1 \%$ PAR depth. 


\section{Discussion}

\subsection{Comparison of Uummannaq Fjord and Vaigat-Disko Bay}

The two systems investigated in this study, Uummannaq and Vaigat-Disko Bay, are in the same area of West Greenland. Both coastal systems are fed by the same inland glacier, and both open to the same ocean end member (Baffin Bay); however, we observed significant differences in their biooptical conditions. Based on observations derived from in situ fluorescence profiles calibrated by laboratory analysis $\left(R^{2}=0.70\right)$, Chl $a$ concentrations $\left(>10 \mu \mathrm{g} \mathrm{L}^{-1}\right)$ were higher in the Vaigat, whereas lower concentrations were measured in Uummannaq Fjord and Disko Bay. Chl $a$ concentrations derived from satellite imagery in July-August 2012 (http://oceancolor.gsfc.nasa.gov/cms/; last access: 29 April 2015) were similar to values reported here, and are also similar to data previously collected from the Vaigat in $\mathrm{Au}-$ gust 1993 (Jensen et al., 1999). These reports indicate that higher amounts of phytoplankton biomass occur in the Vaigat during this time of the year, but Uummannaq Fjord and Disko Bay have comparatively low levels of biomass accumulation. One potential reason for the higher concentrations in the Vaigat may be the favorable current system in Disko Bay as well as freshwater runoff, which contain higher nutrient levels. In contrast, Heide-Jørgensen et al. (2007) reported that Chl $a$ concentrations were higher in Disko Bay than in the Vaigat from April to June (2001-2004), based on data derived from satellite observations. These data were acquired earlier in the year, suggesting the presence of an algal bloom in Disko Bay following the winter ice cover melt.

In Uummannaq Fjord, most surface waters flow from the glaciers towards the open ocean. This water is rich in mineral particles (particularly near the glacier), originating from ice melt and runoff into the fjord. Horizontal water transport and vertical water mixing in the fjord, as well as sinking of sediment particles in the water column, produce horizontal and vertical SPMi gradients (derived with Eq. $7\left(R^{2}=0.69\right)$ from sampled data). Strong ice melt reported in 2012 may have led to increased inorganic SPM influxes; however, this speculation requires validation from multi-year observations or through sediment sampling. Waters in Uummannaq Fjord were also characterized by low phytoplankton biomass.

These observations are similar to data collected in August 2007 from Kangerlussuaq Fjord in West Greenland (Lund-Hansen et al., 2010), which is of comparable geography as Uummannaq Fjord. This study found that SPMi concentrations at most stations in Kangerlussuaq Fjord were slightly higher than in Uummannaq Fjord, but that Chl $a$ concentrations were comparable. Mean aCDOM measured in both systems also showed a similar range of values (Table 3). Mean CDOM absorption in Kangerlussuaq Fjord was $440 \mathrm{~nm}$, and values ranged from 0.046 to $0.36 \mathrm{~m}^{-1}$, with the higher values measured near meltwater outlets (Lund-
Hansen et al., 2010). Converting the aCDOM results from Table 3 to $440 \mathrm{~nm}$ yields a similar range in Uummannaq Fjord (mean $0.07 \mathrm{~m}^{-1}$, maximum $0.48 \mathrm{~m}^{-1}$ ) and VaigatDisko Bay (mean $0.11 \mathrm{~m}^{-1}$, maximum $0.61 \mathrm{~m}^{-1}$ ). Lower variability was observed near the Perlerfiup Sermia glacier in Uummannaq Fjord (Fig. 4e) compared with data from the outer fjord and Vaigat-Disko Bay (Fig. 4f); thus, in contrast to typical estuarine environments, CDOM absorption and salinity appear to be coupled in this system (Garaba et al., 2014; Murray et al., 2015).

Temperature and salinity data indicate that surface waters of both Uummannaq Fjord and Vaigat-Disko Bay were warmer and less saline compared to waters found at depth, due to meltwater influence and solar heating at the air-water surface. Meltwater influence was also shown by higher SPMi concentrations in surface waters at some stations (e.g., 506 and 512, Fig. 3). Similar phenomena were also reported previously by Farmer and Freeland (1983).

\subsection{Light penetration in an integrated bio-optical representation}

Photosynthetically available radiation (PAR) profiles were derived based on a model adapted from Buiteveld (1995), with local parameterization of $k_{\mathrm{PAR}}$ following Gohin et al. (2005). Comparison of modeled values with measured PAR profiles from the free falling profiler and their calculated $1 \%$ depth of PAR shows good correlation $\left(R^{2}=0.92\right)$, with a slight underestimation of the penetration depth. Segmenting the data and formulating two models led to better results for Uummannaq Fjord $\left(R^{2}=0.52\right)$ but worse results in VaigatDisko Bay; therefore, we elected to create a single model for the area. In addition, the resulting model provided rapid estimates of light availability within these meltwater-influenced Arctic systems based on water sample analysis and data from common bio-optical sensors (fluorescence and turbidity) provided by CTD profiles. This is particularly advantageous, as the use of PAR sensors attached to CTD water sampler frames is discouraged, due to shadowing from the ship and the presence of the bulky CTD itself, both of which influence the underwater light field (Weir et al., 1994).

High abundances of SPMi and Chl $a$ significantly influenced the light penetration depth, as evidenced from changes in the $1 \%$ PAR depth in both coastal systems. In contrast, the influence of CDOM on the underwater light field was less relevant, reflected by low CDOM absorption measured throughout this study. Due to this, the absorption of CDOM was considered to be constant in the PAR model, and combined with pure seawater attenuation in Eq. (4). Based on this approach and the bio-optical conditions observed, parameterization of the diffuse attenuation coefficient $k_{\text {PAR }}$ was specified (Eq. 8) and subsequently utilized to fill observational gaps due to the absence of PAR profiles under unfavorable light conditions.

As expected, the DCM was consistently observed above the $1 \%$ PAR depth, emphasizing the limiting role of light in 
photosynthetic growth. The DCM depth was also at or above the depth of the warm surface water layer detected in the coastal systems, suggesting that temperature was a further limiting factor in photosynthetic growth. An integrated perspective is presented by Figs. 8 and 9, which simplify the bio-optical data to a comparative scale. Differences in DCM, DSM, and $1 \%$ PAR depth of the two adjacent coastal systems are thus visualized, facilitating the assessment of key variables used to determine light availability in these coastal systems. To illustrate the importance of SPMi to the underwater light field, particularly in a changing environment, we increased the SPMi concentrations by $50 \%$ in the model representation. This led to a $12-30 \%$ reduction in the $1 \%$ depth PAR at stations with higher SPMi concentrations, and up to an $8 \%$ reduction at stations with lower concentrations.

\section{Conclusions}

In this study we present the findings of a physical-bio-optical investigation of Uummannaq Fjord and the Vaigat-Disko Bay system, two embayments on the western coast of Greenland. Despite their close proximity to one another and similar orientation (the boundaries of both include the Greenland ice sheet and Baffin Bay), the two systems differ significantly with respect to their bio-optical conditions and biological activity. Chlorophyll was significantly higher in the Vaigat, and inorganic suspended particulate matter concentrations were highest near sources of freshwater influx in these systems. The latter corresponded to the introduction of fine sediments, also known as glacial flour, by glacial meltwater. CDOM absorption exhibited only small differences between the two systems, and was generally found at low concentrations. Consequently, Chl $a$ and SPMi were identified as the primary determinants of the underwater light field characteristics and the resulting 1\% PAR depth. A simple two-component PAR model was developed to fill observational gaps resulting from unfavorable light conditions during field collections. This model estimated light penetration depth from Chl $a$ and SPMi concentrations, both under the observed field conditions and those expected from increased ice melt as a consequence of a warming climate.

This study also revealed the complexity of the Greenland coastal systems. Murray et al. (2015) suggested that Greenland's fjords are different from typical riverine estuaries, since freshwater influx often contains higher amounts of sediments but does not provide significant nutrient and CDOM inputs, with both originating primarily from the marine side. Our investigation confirmed this mechanism; however, the simplified biogeography of a long narrow fjord terminated by either glacier or ocean does not hold true here. Uummannaq Fjord has a number of tributary smaller fjords and numerous runoffs from the fjord sidewalls, whereas Vaigat-Disko Bay is a large embayment system that includes several horizontal circulation patterns, as well as a variety of deeper channels and extended shallow areas. Assessing the ecological mechanisms within these systems will therefore require an integrated observational strategy that includes different spatiotemporal scales, and links to high-resolution models (Zielinski et al., 2009). With these in operation, it will be possible to investigate conditions during time frames beyond the availability of observational data, and to distinguish the effects of short-term events, such as the extreme ice melt observed in 2012, from long-term trends in the Greenland ice sheet.

Acknowledgements. We want to thank the master and crew of R/V Maria S. Merian as well as chief scientist Allan Cembella for their support during MSM21/3. Our gratitude is expressed to Daniela Meier, Daniela Voß and Rohan Henkel for their help during and after the expedition. We are grateful to Don Anderson, Julia Busch, Ursel Gerken and Mindy Richlen for their assistance and review of this manuscript. The helpful comments of the three reviewers and the editor are also gratefully acknowledged.

Edited by: M. Hoppema

\section{References}

Andersen, O. G. N.: The annual cycle of temperature, salinity, currents and water masses in Disko Bugt and adjacent waters, West Greenland, Monographs on Greenland, 217, Museum Tusculanums Press, Copenhagen, 1981.

Arar, E. J.: Method 446.0: In Vitro Determination of Chlorophylls $\mathrm{a}, \mathrm{b}, \mathrm{c}+\mathrm{c}$ and Pheopigments in Marine And Freshwater Algae by Visible Spectrophotometry, Report, United States Environmental Protection Agency, Office of Research and Development, National Exposure Research Laboratory, Cincinatti, Ohio, USA, 1997.

Bannister, T. T.: A general theory of steady state phytoplankton growth in a nutrient saturated mixed layer, Limnol. Oceanogr., 19, 13-30, doi:10.4319/lo.1974.19.1.0013, 1974.

Behrenfeld, M. J. and Falkowski, P. G.: A consumer's guide to phytoplankton primary productivity models, Limnol. Oceanogr., 42, 1479-1491, doi:10.4319/lo.1997.42.7.1479, 1997.

Buiteveld, H.: A model for calculation of diffuse light attenuation (PAR) and Secchi depth, Netherlands Journal of Aquatic Ecology, 29, 55-65, 1995.

Cembella, A., Zielinski, O., Anderson, D., Graeve, M., Henkel, R., John, U., Kattner, G., Koch, B., Krock, B., Meier, D., Richlen, M., Tillmann, U., and Voß, D.: ARCHEMHAB: Interactions and feedback mechanisms between hydrography, geochemical signatures and microbial ecology, with a focus on HAB species diversity, biogeography and dynamics, Report, DFGSenatskommission für Ozeanographie, Bremen, Germany, 2013.

Cuny, J., Rhines, P. B., Schott, F., and Lazier, J.: Convection above the Labrador continental slope, J. Phys. Oceanogr., 35, 489-511, doi:10.1175/Jpo2700.1, 2005.

Duyens, L. N. M.: The flattering of the absorption spectrum of suspensions, as compared to that of solutions, Biochim. Biophys. Acta, 19, 1-12, doi:10.1016/0006-3002(56)90380-8, 1956.

Etherington, L. L., Hooge, P. N., Hooge, E. R., and Hill, D. F.: Oceanography of Glacier Bay, Alaska: Implications for biologi- 
cal patterns in a glacial fjord estuary, Estuar. Coast., 30, 927-944, doi:10.1007/bf02841386, 2007.

Amante, C. and Eakins, B. W.: ETOPO1 1 Arc-Minute Global Relief Model: Procedures, Data Sources and Analysis, National Centers of Environmental Information, doi:10.7289/V5C8276M, 2009

Farmer, D. M. and Freeland, H. J.: The Physical Oceanography of Fjords, Prog. Oceanogr., 12, 147-219, doi:10.1016/00796611(83)90004-6, 1983.

Garaba, S. P. and Zielinski, O.: Comparison of remote sensing reflectance from above-water and in-water measurements west of Greenland, Labrador Sea, Denmark Strait, and west of Iceland, Opt. Express, 21, 15938-15950, doi:10.1364/OE.21.015938, 2013.

Garaba, S. P., Voß, D., and Zielinski, O.: Physical, Bio-Optical State and Correlations in North-Western European Shelf Seas, Remote Sens., 6, 5042-5066, doi:10.3390/rs6065042, 2014.

Gohin, F.: Annual cycles of chlorophyll- $a$, non-algal suspended particulate matter, and turbidity observed from space and in-situ in coastal waters, Ocean Sci., 7, 705-732, doi:10.5194/os-7-7052011, 2011.

Gohin, F., Loyer, S., Lunven, M., Labry, C., Froidefond, J. M., Delmas, D., Huret, M., and Herbland, A.: Satellite-derived parameters for biological modelling in coastal waters: illustration over the eastern continental shelf of the Bay of Biscay, Remote Sens. Environ., 95, 29-46, doi:10.1016/j.rse.2004.11.007, 2005.

Hansen, M. O., Nielsen, T. G., Stedmon, C. A., and Munk, P.: Oceanographic regime shift during 1997 in Disko Bay, Western Greenland, Limnol. Oceanogr., 57, 634-644, doi:10.4319/lo.2012.57.2.0634, 2012.

Heide-Jørgensen, M. P., Laidre, K. L., Logsdon, M. L., and Nielsen, T. G.: Springtime coupling between chlorophyll a, sea ice and sea surface temperature in Disko Bay, West Greenland, Prog. Oceanogr., 73, 79-95, doi:10.1016/j.pocean.2007.01.006, 2007.

Jensen, H. M., Pedersen, L., Burmeister, A. D., and Hansen, B. W.: Pelagic primary production during summer along 65 to $72^{\circ} \mathrm{N}$ off West Greenland, Polar Biol., 21, 269-278, doi:10.1007/s003000050362, 1999.

Joughin, I., Smith, B. E., Shean, D. E., and Floricioiu, D.: Brief Communication: Further summer speedup of Jakobshavn Isbræ, The Cryosphere, 8, 209-214, doi:10.5194/tc-8-209-2014, 2014.

Lund-Hansen, L. C., Andersen, T. J., Nielsen, M. H., and Pejrup, M.: Suspended Matter, Chl-a, CDOM, grain sizes, and optical properties in the arctic Fjord-Type Estuary, Kangerlussuaq, West Greenland during summer, Estuar. Coast., 33, 1442-1451, doi:10.1007/s12237-010-9300-7, 2010.

Melling, H., Gratton, Y., and Ingram, G.: Ocean circulation within the North Water polynya of Baffin Bay, Atmosphere-Ocean, 39, 301-325, doi:10.1080/07055900.2001.9649683, 2010.

Moore, C., Barnard, A., Fietzek, P., Lewis, M. R., Sosik, H. M., White, S., and Zielinski, O.: Optical tools for ocean monitoring and research, Ocean Sci., 5, 661-684, doi:10.5194/os-5-6612009, 2009.

Moore, S. K., Trainer, V. L., Mantua, N. J., Parker, M. S., Laws, E. A., Backer, L. C., and Fleming, L. E.: Impacts of climate variability and future climate change on harmful algal blooms and human health, Environ. Health, 7 Suppl 2, S4, doi:10.1186/1476069X-7-S2-S4, 2008.
Munchow, A., Melling, H., and Falkner, K. K.: An observational estimate of volume and freshwater flux leaving the arctic ocean through nares strait, J. Phys. Oceanogr., 36, 2025-2041, doi:10.1175/Jpo2962.1, 2006.

Murray, C., Markager, S., Stedmon, C. A., Juul-Pedersen, T., Sejr, M. K., and Bruhn, A.: The influence of glacial melt water on biooptical properties in two contrasting Greenland fjords, Estuarine, Coast. Shelf Sci., 163, 72-83, doi:10.1016/j.ecss.2015.05.041, 2015.

Nelson, D. M. and Smith, W. O.: Sverdrup revisited - critical depths, maximum chlorophyll levels, and the control of Southern-Ocean productivity by the irradiance-mixing regime, Limnol. Oceanogr., 36, 1650-1661, 1991.

Nghiem, S. V., Hall, D. K., Mote, T. L., Tedesco, M., Albert, M. R., Keegan, K., Shuman, C. A., DiGirolamo, N. E., and Neumann, G.: The extreme melt across the Greenland ice sheet in 2012, Geophys. Res. Lett., 39, L20502, doi:10.1029/2012g1053611, 2012.

Paulson, C. A. and Simpson, J. J.: Irradiance measurements in the upper ocean, J. Phys. Oceanogr., 7, 952-956, doi:10.1175/15200485(1977)007<0952:imituo>2.0.co;2, 1977.

Platt, T. and Sathyendranath, S.: Oceanic primary production: estimation by remote sensing at local and regional scales, Science, 241, 1613-1620, doi:10.1126/science.241.4873.1613, 1988.

Ribergaard, M. H., Pedersen, S. A., Ådlandsvik, B., and Kliem, N.: Modelling the ocean circulation on the West Greenland shelf with special emphasis on northern shrimp recruitment, Cont. Shelf Res., 24, 1505-1519, doi:10.1016/j.csr.2004.05.011, 2004.

Straneo, F. and Cenedese, C.: The Dynamics of Greenland's Glacial Fjords and Their Role in Climate, Ann. Rev. Mar. Sci., 7, 89-112, doi:10.1146/annurev-marine-010213-135133, 2015.

Straneo, F., Sutherland, D. A., Holland, D., Gladish, C., Hamilton, G. S., Johnson, H. L., Rignot, E., Xu, Y., and Koppes, M.: Characteristics of ocean waters reaching Greenland's glaciers, Ann. Glaciol., 53, 202-210, doi:10.3189/2012AoG60A059, 2012.

Tang, C. C. L., Ross, C. K., Yao, T., Petrie, B., DeTracey, B. M., and Dunlap, E.: The circulation, water masses and sea-ice of Baffin Bay, Prog. Oceanogr., 63, 183-228, doi:10.1016/j.pocean.2004.09.005, 2004.

Vahtera, E., Crespo, B. G., McGillicuddy, D. J., Olli, K., and Anderson, D. M.: Alexandrium fundyense cyst viability and germling survival in light vs. dark at a constant low temperature, Deep-Sea Res. Pt. II, 103, 112-119, doi:10.1016/j.dsr2.2013.05.010, 2014.

Weir, C. T., Siegel, D. A., Michaels, A. F., and Menzies, D. W.: In-situ evaluation of a ship's shadow, 2258, 815-821, doi:10.1117/12.190130, 1994.

Zielinski, O., Llinas, O., Oschlies, A., and Reuter, R.: Underwater light field and its effect on a one-dimensional ecosystem model at station ESTOC, north of the Canary Islands, Deep-Sea Res. Pt. II, 49, 3529-3542, doi:10.1016/S0967-0645(02)00096-6, 2002.

Zielinski, O., Busch, J. A., Cembella, A. D., Daly, K. L., Engelbrektsson, J., Hannides, A. K., and Schmidt, H.: Detecting marine hazardous substances and organisms: sensors for pollutants, toxins, and pathogens, Ocean Sci., 5, 329-349, doi:10.5194/os5-329-2009, 2009.

Zielinski, O., Voß, D., Meier, D., Henkel, R., Holinde, L., Garaba, S. P., and Cembella, A.: Physical oceanography during Maria S. Merian cruise MSM21/3 (ARCHEMHAB), PAN- 
GAEA - Data Publisher for Earth \& Environmental Science, doi:10.1594/pangaea.819731, 2013a.

Zielinski, O., Voß, D., Meier, D., Henkel, R., Holinde, L., Garaba, S. P., and Cembella, A.: Total suspended matter, particulate organic matter, and particulate inorganic matter during Maria S. Merian cruise MSM21/3 (ARCHEMHAB), PANGAEA - Data Publisher for Earth \& Environmental Science, doi:10.1594/PANGAEA.810708, 2013b.

Zielinski, O., Voß, D., Meier, D., Henkel, R., Holinde, L., Garaba, S. P., and Cembella, A.: Chlorophyll a during Maria S. Merian cruise MSM21/3 (ARCHEMHAB), PANGAEA - Data Publisher for Earth \& Environmental Science, doi:10.1594/PANGAEA.810651, 2013c.
Zielinski, O., Voß, D., Meier, D., Henkel, R., Holinde, L., Garaba, S. P., and Cembella, A.: Colored dissolved organic matter during Maria S. Merian cruise MSM21/3 (ARCHEMHAB), PANGAEA - Data Publisher for Earth \& Environmental Science, doi:10.1594/PANGAEA.810861, 2013d.

Zweng, M. M. and Munchow, A.: Warming and freshening of Baffin Bay, 1916-2003, J. Geophys. Res.-Oceans, 111, C07016, doi:10.1029/2005jc003093, 2006. 